\title{
МОНІТОРИНГ ПОШИРЕНОСТІ РОЗЛАДІВ ПСИХІКИ ТА ПОВЕДІНКИ ВНАСЛІДОК ВЖИВАННЯ ПСИХОАКТИВНИХ РЕЧОВИН СЕРЕД НАСЕЛЕННЯ М. ЛЬВОВА ТА ЛЬВІВСЬКОЇ ОБЛАСТІ
}

О. С. Фітькало

Львівський наџіональний медичний університет імені Данила Галищького

\author{
THE MONITORING OF PREVALENCE OF MENTAL AND \\ BEHAVIOURAL DISORDERS AS A RESULT OF PSYCHOACTIVE \\ SUBSTANCES CONSUMPTION IN LVIV AND LVIV REGION
}

\author{
Lviv National Medical University by Danylo Halytskyi
}

\begin{abstract}
У статті представлений аналіз захворюваності, поширеності на розлади психіки та поведінки внаслідок вживання психоактивних речовин у м. Львові та Львівській області впродовж 2010-2012 рр., який проведений за принципом моніторингу.
\end{abstract}

The article presents the analysis of morbidity, prevalence of mental and behavioural disorders as a result of psychoactive substances consumption in Lviv and Lviv region during 2010-2012, which is provided according to the monitoring principle.

Вступ. Залежність від психоактивних речовин (ПАР) $є$ проблемою цілого світу і становить особливу загрозу, як жодна хвороба, тому що призводить до значних економічних, моральних збитків, духовного розкладу суспільства, загрожує генофонду нації, державній і національній безпеці $[1,3]$. Статистичні дані ВООЗ, які були оприлюднені у вересні 2011 року, підтверджують важливість цієї проблеми. Відомо, що населення планети складає 7 мільярдів людей, 3 них 210 мільйонів споживають наркотики. За тими ж даними, середній вік, у якому людина починає вживати наркотики, складає 15-17 років.

Говорячи про проблему залежності, ми не можемо не вказати на те, що у 2010 році зареєстровано рекордне число появи нових видів наркотиків - 41 (за даними Europian Monitoring Centre for Drugs and Drug Addiction), до складу яких входять не заборонені законом речовини. У 2011 р. нових препаратів нараховувалось 39. Крім того, у 2011 році збільшилась поширеність продажу наркотиків через мережу Internet. Незважаючи на таку критичну ситуацію, у світі існують організації, які вважають, що потрібно легалізувати наркотики і таким чином позбутись проблеми залежності.

Індикатором стану проблеми $є$ рівень захворюваності та поширеності розладів психіки та поведінки внаслідок вживання ПАР, а оцінка стану захворюваності може вирішуватись шляхом проведення системного моніторингу. Завданням моніторингу $є$ аналіз системи обліку захворюваності та поширеності зловживанням ПАР, що дасть можливість підвищити ефективність діяльності спеціалізованих медичних закладів.

За даними Центру медичної статистики МОЗ України станом на 01.01.2013 р., поширеність розладів психіки та поведінки внаслідок вживання наркотичних речовин склала 77105 осіб, що становить 169,1 на 100 тисяч населення. В умовах сучасної України хворі на нарко-токсикоманію потенційно спроможні подвоювати чисельність майже кожні три роки, а хворі на алкоголізм - кожні два роки. В останні роки поширилося зловживання не тільки алкогольними напоями, а й поєднане вживання (алкоголь+наркотики ) $[2,4]$.

Рівень захворюваності населення на розлади психіки та поведінки внаслідок вживання психоактивних речовин на Львівщині $є$ вдвічі нижчим, ніж в Україні загалом. Серед регіонів за цим показником область займає 20, а може навіть 23 місце. Однак це нас не тішить. Коли подивитись на статистику, то в основному це молоді працездатні люди від 17 до 35 років. Крім того, офіційна система статистики не дозволяє

(с) О. С. Фітькало 
відслідкувати реального стану речей, пов'язаного зі здоров' ям населення регіону з приводу зловживання ПАР, як, наприклад, сільське населення, де показник $є$ занадто низьким. Зрозуміло, що він не відображає реальної картини - адже медикам відомо, що сільські жителі за медичною допомогою з приводу зловживання звертаються досить рідко. Тоді як стан, у якому хворі потрапляють у стаціонар, є вкрай важким і потребує негайної госпіталізації, яка рідко закінчується ремісією. Ми зовсім не володіємо інформацією про кількість пацієнтів, які отримують наркологічну допомогу у приватних клініках.

Мета роботи: $є$ вивчення ситуації, на основі аналізу проведеного моніторингу захворюваності, яка пов'язана із поширеністю психічних та поведінкових розладів внаслідок вживання психоактивних речовин серед населення Львівської області та м. Львова.

Основна частина. Наше моніторингове дослідження із викладом порівняльних результатів дослідження включало ряд показників. На першому місці був проведений аналіз числа осіб, які вперше звернулись за медичною допомогою. Згідно зі статис- тичною звітністю Львівського обласного державного клінічного наркологічного диспансеру за 20102012 рр., ситуація виглядає таким чином: кількість осіб, взятих на облік із вперше у житті встановленим діагнозом з приводу розладів психіки і поведінки внаслідок вживання алкоголю, у 2010 р. в абсолютних числах склала 2158, у 2012 році цей показник був нижчий на 17,6\% і складав 1777 осіб. Всього у 2012 році зареєстровано 34767 осіб, які зловживають алкоголем і мають розлади психіки та поведінки. Стан відміни з делірієм у 2010р. в абсолютних числах склав 244 особи, у 2012 р. - 105 осіб, що складає менше ніж половину порівняно з 2010 р. (табл. 1).

При зловживанні наркотичними та токсичними речовинами зареєстровано вперше у 2010 році в абсолютних числах - 190 осіб, тоді як у 2012 р. ця кількість зменшилась на 33 особи і склала уже 157 осіб. Коли ж взяти поширеність зловживання наркотичними речовинами, то дана статистика виглядає так: 2010 р. - 1158 осіб, 2012 р. - 1254 особи. Як бачимо, загальна кількість осіб, що вживають наркотичні речовини, збільшилась на 8,3\% (табл. 1, 2).

Таблиця 1. Захворюваність на розлади психіки та поведінки внаслідок зловживання алкоголем, наркотичними й токсичними речовинами

\begin{tabular}{|c|c|c|c|c|c|c|c|c|}
\hline \multirow{4}{*}{ Роки } & \multicolumn{8}{|c|}{ 3ахворюван ість } \\
\hline & \multirow{2}{*}{\multicolumn{2}{|c|}{ Всього }} & \multicolumn{6}{|c|}{ в тому числі } \\
\hline & & & \multicolumn{2}{|c|}{$\begin{array}{c}\text { розлади психіки і } \\
\text { поведінки внаслі- } \\
\text { док уживання } \\
\text { алкоголю }\end{array}$} & \multicolumn{2}{|c|}{ стан відміни $з$ делірієм } & \multicolumn{2}{|c|}{$\begin{array}{c}\text { розлади психіки і } \\
\text { поведінки внаслідок } \\
\text { уживання наркотичних } \\
\text { та токсичних речовин }\end{array}$} \\
\hline & $\begin{array}{c}\text { абс. } \\
\text { число }\end{array}$ & $\begin{array}{c}\text { на } 10 \\
\text { тис. }\end{array}$ & $\begin{array}{c}\text { абс. } \\
\text { число }\end{array}$ & $\begin{array}{c}\text { на } 10 \\
\text { тис. }\end{array}$ & $\begin{array}{c}\text { абс. } \\
\text { число }\end{array}$ & $\begin{array}{c}\text { на } 10 \\
\text { тис. }\end{array}$ & $\begin{array}{c}\text { абс. } \\
\text { число }\end{array}$ & $\begin{array}{c}\text { на } 10 \\
\text { тис. }\end{array}$ \\
\hline 2010 & 2592 & 10,2 & 2158 & 8,5 & 244 & 1,0 & 190 & 0,8 \\
\hline 2011 & 2274 & 9,0 & 1999 & 7,9 & 101 & 0,4 & 174 & 0,7 \\
\hline 2012 & 2039 & 8,1 & 1777 & 7,0 & 105 & 0,4 & 157 & 0,6 \\
\hline
\end{tabular}

Таблиця 2. Поширеність розладів психіки та поведінки внаслідок зловживання алкоголем, наркотичними й токсичними речовинами

\begin{tabular}{|c|c|c|c|c|c|c|c|c|}
\hline \multirow{4}{*}{ Роки } & \multicolumn{8}{|c|}{ Поширеність } \\
\hline & \multirow{2}{*}{\multicolumn{2}{|c|}{ Всього }} & \multicolumn{6}{|c|}{ в тому числі } \\
\hline & & & \multicolumn{2}{|c|}{$\begin{array}{c}\text { розлади психіки і } \\
\text { поведінки внаслі- } \\
\text { док уживання } \\
\text { алкоголю } \\
\end{array}$} & \multicolumn{2}{|c|}{ стан відміни з делірієм } & \multicolumn{2}{|c|}{$\begin{array}{c}\text { розлади психіки і } \\
\text { поведінки внаслідок } \\
\text { уживання наркотичних та } \\
\text { токсичних речовин } \\
\end{array}$} \\
\hline & $\begin{array}{c}\text { абс. } \\
\text { число }\end{array}$ & $\begin{array}{c}\text { на } 10 \\
\text { тис. }\end{array}$ & $\begin{array}{c}\text { абс. } \\
\text { число }\end{array}$ & $\begin{array}{c}\text { на } 10 \\
\text { тис. }\end{array}$ & $\begin{array}{c}\text { абс. } \\
\text { число }\end{array}$ & $\begin{array}{c}\text { на } 10 \\
\text { тис. }\end{array}$ & $\begin{array}{c}\text { абс. } \\
\text { число }\end{array}$ & $\begin{array}{l}\text { на } 10 \\
\text { тис. }\end{array}$ \\
\hline 2010 & 35890 & 141,8 & 34374 & 135,8 & 358 & 1,4 & 1158 & 4,6 \\
\hline 2011 & 35878 & 142,0 & 34538 & 136,7 & 151 & 0,6 & 1189 & 4,7 \\
\hline 2012 & 36170 & 143,4 & 34767 & 137,8 & 149 & 0,6 & 1254 & 5,0 \\
\hline
\end{tabular}

Контингент усіх осіб (поширеність), які мають розлади психіки через уживання психоактивних речовин, станом на 01.01.2013 р. становив 36170 особи.
Отримані під час дослідження дані свідчать, що небезпечним $є$ вік пацієнтів (17 - 35 років), які нараховували 8031 особу, сільських жителів - 15 252, на 
наркологічний облік поставлено 5 осіб у віці до 17 років. Як бачимо, максимальну питому вагу у структурі загальної поширеності займали розлади психіки та поведінки внаслідок зловживання молодими особами працездатного віку 15-35 років, яких на 16.01.2013 р. нараховувалась в абсолютних одиницях 8031 особа. Ця цифра вкрай тривожить, адже молоді люди у віці 17-35 років складають левову частку таких пацієнтів-22, $2 \%$. За неофіційною статистикою, таких пацієнтів за підрахунками має бути вдвічі більше (табл. 2).

Позитивним залишається той факт, що медичною допомогою охоплені практично всі пацієнти. На амбулаторному та стаціонарному лікуванні у 2012 році перебувало, відповідно, 20201 та 5525 пацієнтів, що в процентному відношенні склало 55, 5 \% і 15,3 \%, на диспансерному обліку знаходиться $25726-71,1 \%$ відповідно.

Проводився також аналіз захворюваності з приводу вживання алкоголю в районах та містах Львівської області та м. Львові. Пустомитівський район, де найбільший показник зловживання алкоголем, у 2010 p. кількість осіб, які вперше звернулись з приводу розладів психіки через вживання алкоголю, нараховано в абсолютних числах 136 осіб, 2011 р. - 115, 2012 р. 99 осіб. Найнижча захворюваність 3 приводу вживання алкоголю спостерігається в Турківському районі, який $є$ найбільш віддалений від м. Львова. Тут поряд із низькою захворюваністю проглядається чітка стабілізація показників - у 2010 р. на обліку стояло 22 особи, у 2011 та 2012 рр. ця цифра склала 14 осіб. У м. Львові зареєстровано найбільшу кількість осіб, які зловживають алкоголем, відповідно, в 2010 р. 897 осіб, у 2011 р. - 738, у 2012 р. - 677. Осіб, які зловживають наркотичними речовинами, відповідно: 2010 p. $-101,2011$ p. $-83,2012$ p. -82. Поширеність : 2010 p. $-582,2011$ p. $-626,2012$ p. -670 осіб.

За даними статистики обласного наркодиспансеру по Львову та Львівській області, у 2012 р. на обліку офіційно зареєстрованих осіб, що зловживали наркотичними засобами - 1254 особи, вперше виявлених 157, серед них молоді люди у віці від 17 до 35 років - 130, та 2 підлітки у віці до 17 років, сільських жителів 16.

Висновок. Порівняно 3 попередніми роками оцінки стану здоров'я населення м. Львова та Львівської області засвідчено певну динаміку зниження захворюваності й збільшення поширеності розладів психіки та поведінки внаслідок вживання психоактивних речовин.

Представлені дані, які отримані в результаті проведеного моніторингу, виявили тенденцію до зниження захворюваності на розлади психіки та поведінки внаслідок вживання психоактивних речовин, однак вживання ПАР є досить поширеним явищем, тому проблема залишається актуальною і свідчить про доцільність їі подальшого аналізу та впровадження ефективних профілактичних та лікувальних заходів.

Проведення такого і аналогічного моніторингу дасть можливість в подальшому здійснити ефективні профілактичні заходи, які будуть направлені на донесення критичної ситуації, яка склалась внаслідок вживання психоактивних речовин, через засоби масової інформації. Найбільш надійний засіб боротьби з наркоманією - недопущення первинного звернення молодих людей до наркотиків.

Пропозииії. Проводячи моніторинг 3 приводу захворювання та поширення на розлади психіки та поведінки внаслідок вживання психоактивних речовин у Західному регіоні, вважаємо, що ми повинні змінити своє ставлення до осіб, залежних від вживання психоактивних речовин, і не вважати, що ценас нестосується. 'Хочеш змінити світ? Розпочни із себе!”. Можливостей для цього цілком досить. Від п'яного водія до поширювача марихуани в школі. Спокусити людину алкоголем - найлегший спосіб позбавити ії можливості задуматися над своїм розвитком, не кажучи вже про досягнення в ньому нових, неперевершених результатів. Це найпростіший спосіб запустити механізм деградації не тільки якоїсь окремої особистості, але й усього суспільства в цілому.

Сьогодні теорія культурного споживання алкогольних напоїв (від сімейних уродин до релігійних свят) призводить до того, що люди позитивно сприймають алкоголь. Тоді як алкоголь $\epsilon$ страшною отрутою і немає нешкідливих доз, а кількість вживаного спиртного, за нашими спостереженнями, буде збільшуватись.

На відміну від багатьох інших країн, у нас дозволена реклама алкогольних напоїв, яка активно поширюється всіма засобами масової інформації. Найбільш ходовим товаром, який завжди наявний на ринку, є дешеві горілчані вироби, що реалізуються за середніми цінами від 16 до 30 грн. Продаж таких товарів приносить величезні прибутки, тому рекламують його достатньо грамотно і переконливо. Ціна, як бачимо, теж $є$ доступною для всіх. Ні реклама, ні продаж не заборонені. Навіть такий захід, як заборона продавати спиртні напої особам до 18 років, $\epsilon$ більше на папері, ніж діс в буденному житті.

Ми і досі не маємо засобів радикального лікування іпрофілактики алкогольної залежності, можливо тому, що поки що не до кінця з'ясованим залишається ме- 
ханізм дії алкоголю на макроорганізм. Ринок препаратів для лікування хворих від алкогольної залежності $€$ недостатній і представлений невеликою кількістю

\section{Література}

1. Актуальні тенденції поширення залежності від психоактивних речовин в Україні : щорічний аналітичний огляд / [І. В. Лінський, М. В. Голубчиков, О. І. Мінко та ін.]. - Харків, 2006. - Вип. 3. -46 с.

2. Епідеміологічна ситуація щодо вживання психоактивних речовин в Україні / С. І. Табачніков, Д. С. Лєбєдєв, Г. Є. Трофімчук [та ін.] // Архів психіатрії. - 2009. -№ 1. -С. 56-59. препаратів, причому майже повністю відсутні вітчизняні аналоги комплексної профілактичної і лікувальноїдій.

3. Зріз наркотичної ситуації в Україні (дані 2010 року). Київ, 2011.-22 с.

4. Епідеміологічна ситуація, що склалася внаслідок розповсюдження залежності від психоактивних речовин в Україні / П. В. Волошин, О. І. Мінко, І. В. Лінський [та ін.] // Укр. вісник психоневрології. -2001. - Т. 9, вип. 3. - С. 7-9. 